\title{
KIAA1549/BRAF Fusion Protein
}

National Cancer Institute

\section{Source}

National Cancer Institute. KIAA1549/BRAF Fusion Protein. NCI Thesaurus. Code C99844.

A fusion protein encoded by the KIAA1549/BRAF fusion gene. This protein is comprised

of half of the N-terminus of the putative UPF0606 protein KIAA1549 fused to the Cterminal half of the serine/threonine-protein kinase B-raf protein. 